\title{
Pembangunan Sistem Informasi Manajemen Diklat Menggunakan Metode Servqual Dalam Upaya Meningkatkan Kualitas Pelayanan Informasi (Studi Kasus: Balai Diklat Metrologi)
}

\author{
Erwin Yulianto ${ }^{1}$,Arief Ginanjar ${ }^{2}$ \\ Program Studi Informatika, Universitas Langlangbuana \\ rwinyulianto@yahoo.com ${ }^{1}$,agienthea@gmail.com ${ }^{2}$
}

\begin{abstract}
The Metrology Training Center is currently improving itself by developing facilities and infrastructure including improvements in terms of information servicesquality.Improvements currently carried out are unfortunately not in line with the quality of information services both internally and externally. This happened because Silo's work culture took place in the Metrology Training Center, which is a current mindset when some certain parts do not want to share information with other parts or sectors in the same organization. This type of mentality will reduce efficiency in the overall business process, reduce moral values, and potentially create a counterproductive organizational culture. In order to improve the quality of information services, the solution to be provided is by buildingEducation and Training Management Information System using the Servqual method. The application development method used is an objectoriented method with the stages of software development life cycle using the Evolutionary Prototype model. With the solution built in the Metrology Training Center, it is expected that the quality of information services expected for external and internal parties can increase.
\end{abstract}

Keywords: Design and Develoment, Management Information System, Education and Training, Servqual Method. Information Service Quality

\begin{abstract}
Abstrak
Balai Diklat Metrologi saat ini tengah berbenah diri dengan mengembangkan fasilitas dan infrastruktur termasuk peningkatan dari segi kualitas pelayanan informasi.Pembenahan-pembenahan yang dilakukan saat ini sayangnya tidak selaras dengan kualitas pelayanan informasi baik di internal instansi maupun secara eksternal. Hal tersebut terjadi karena budaya kerja Silo yang terjadi di Balai Diklat Metrologi, yaitu sebuah pola pikir masa kini ketika beberapa bagian tertentu tidak menginginkan untuk berbagi informasi dengan bagian atau sektor lainnya di dalam organisasi yang sama. Tipe mentalitas seperti ini akan mengurangi efisiensi dalam proses bisnis keseluruhan, mengurangi nilai-nilai moral, dan berpotensi terciptanya budaya organisasi yang kontra produktif. Dalam rangka untuk meningkatkan kualitas pelayanan informasi, maka solusi yang akan diberikan yaitu dengan melakukan pembangunan Sistem Informasi Manajemen Diklat dengan menggunakan metode Servqual. Metode pengembangan aplikasi yang digunakan adalah metode berorientasi objek dengan tahapan software development life cycle menggunakan model Evolutionary Prototype. Dengan adanya solusi yang dibangun pada Balai Diklat Metrologi, diharapkan kualitas layanan informasi yang diharapkan bagi pihak eksternal dan internal dapat meningkat.
\end{abstract}

Kata kunci: Rancang Bangun, Sistem Informasi Manajemen, Pendidikan dan Pelatihan, Metode Servqual, Kualitas Pelayanan Informasi

\section{Pendahuluan}

Balai Diklat Metrologi merupakan sebuah institusi di bawah Pusdiklat Perdagangan Departemen Perdagangan yang terletak di kawasan dataran tinggi Bandung Utara dengan udara yang sangat sejuk dan menempati lahan seluas lebih dari 1,6 hektar. Balai Diklat Metrologi sebagai Unit Pelaksana Teknis (UPT) merupakan satusatunya lembaga pendidikan kemetrologian yang mempunyai peranan yang sangat strategis dan vital didalam rangka mengemban salah satu misi Pusat Pendidikan Pelatihan Perdagangan yaitu pengembangan daya saing dan profesionalisme SDM bidang Perdagangan khususnya yang bertugas di Unit Metrologi di Indonesia.
Balai Diklat Metrologi saat ini tengah berbenah diri dengan mengembangkan fasilitas dan infrastruktur termasuk pembangunan laboratorium baru yang dilengkapi dengan peralatan modern serta sistem administrasi dan keuangan layanan tera [18]. Pembenahan yang dilakukan saat ini sayangnya tidak selaras dengan kualitas pelayanan informasi baik di internal instansi maupun secara eksternal. Hal tersebut terjadi karena budaya kerja Silo yang terjadi di Balai Diklat Metrologi, yaitu sebuah pola pikir masa kini ketika beberapa bagian atau tertentu tidak menginginkan untuk berbagi informasi dengan bagian dan/atau sektor lainnya di dalam organisasi yang sama. Tipe mentalitas seperti ini akan mengurangi efisiensi dalam proses bisnis 
Erwin Yulianto ${ }^{1}$,Arief Ginanjar ${ }^{2}$, Pembangunan Sistem Informasi Manajemen Diklat Menggunakan Metode Servqual Dalam Upaya Meningkatkan Kualitas Pelayanan Informasi (Studi Kasus: Balai Diklat Metrologi)

keseluruhan, mengurangi nilai moral, dan berpotensi terciptanya budaya organisasi yang kontra produktif.

Dalam upaya meningkatkan kualitas pelayanan informasi pendidikan dan pelatihan yang diselenggarakan oleh Balai Diklat Metrologi Departemen Perdagangan diperlukan adanya media informasi berkaitan dengan informasi diklat yang mudah diakses oleh semua pihak, terutama dinas-dinas metrologi di seluruh Indonesia. Media yang dimaksud adalah berupa media informasi berbasis web yang dapat dengan mudah diakses oleh umum.

Berdasarkan fenomena permasalahan yang terjadi di Balai Diklat Metrologi, penulis memiliki kesempatan untuk melakukan pembangunan sebuah sistem informasi manajemen diklat berbasis web dengan menggunakan metode Servqual. Keluaran yang dihasilkan dari penelitian ini adalah implementasi Sistem Informasi Manajemen Diklat yang diharapkan dapat membantu para pengguna sistem informasi seperti admin, peserta diklat, penera, pegawai administrasi, dan pengguna lainnya dalam mengakses informasi terkini, mendapatkan update informasi yang dibutuhkan, menyampaikan kritik, ide dan saran serta informasi di lingkungan Balai Diklat Metrologi.

Tujuan yang ingin dicapai pada penelitian yaitu :

a. Membuat sebuah Sistem Informasi Manajemen Diklat dengan tujuan untuk meningkatkan kualitas layanan informasi dan kemudahan akses informasi baik berupa pengumuman, arsip terkait diklat, maupun dokumentasi foto dari setiap kegiatan / acara bagi pihak internal dan/atau eksternal organisasi.

b. Meningkatkan kinerja Balai Diklat Metrologi dalam hal pengolahan data, penyusunan laporan, dan sentralisasi data untuk mendukung proses penyelenggaraan diklat secara keseluruhan dan terintegrasi.

c. Meningkatkan efektifitas dan juga efisiensi dalam kegiatan belajar mengajar dengan mempermudah pengolahan data jadwal, kelas, materi diklat, pengajar, peserta diklat maupun nilai.

\section{Kajian Pustaka}

\subsection{Rancang Bangun}

Rancang merupakan serangkaian prosedur untuk menerjemahkan hasil analisis dari sebuah sistem kedalam bahasa pemrograman untuk mendeskripsikan dengan detail bagaimana komponen-komponen sistem diimplementasikan, sedangkan pengertian bangun atau pembangunan sistem adalah kegiatan menciptakan hal baru maupun mengganti atau memperbaiki sistem yang telah ada baik secara keseluruhan maupun sebagian [11].

Apabila digabungkan, rancang bangun dapat dikatakan sebagai penggambaran, perencanaan, dan pembuatan sketsa atau pengaturan dari beberapa elemen yang terpisah ke dalam suatu kesatuan yang utuh dan berfungsi. Dengan demikian rancang bangun merupakan kegiatan menerjemahkan hasil analisa ke dalam bentuk paket perangkat lunak kemudian menciptakan sistem tersebut atau memperbaiki sistem yang sudah ada.

Definisi lain dari rancang bangun menurut Ladjamudin (2013) yaitu kegiatan yang memiliki tujuan untuk mendesain sistem baru yang dapat menyelesaikan masalah-masalah yang dihadapi perusahaan melalui pemilihan alternatif sistem yang terbaik. Rancang bangun sangat berkaitan dengan perancangan sistem yang merupakan satu kesatuan untuk merancang dan membangun sebuah aplikasi [8]. Perancangan sistem dapat didefinisikan sebagai gambaran, perencanaan, dan pembuatan sketsa atau pengaturan dari beberapa elemen yang terpisahkan kedalam satu kesatuan yang utuh dan berfungsi. Tujuan dari perancangan sistem yaitu untuk memenuhi kebutuhan para pemakai sistem dan memberikan gambaran yang jelas dan rancang bangun yang lengkap kepada pengembang. Kedua tujuan ini lebih berfokus pada perancangan atau desain sistem yang terinci yaitu pembuatan rancang bangun yang jelas dan lengkap yang nantinya digunakan untuk pembuatan program komputernya [7].

Dari penjelasan diatas dapat disimpulkan bahwa rancang bangun sistem merupakan kegiatan menterjemahkan hasil analisa ke dalam bentuk paket perangkat lunak kemudian menciptakan sistem tersebut atau memperbaiki sistem yang ada.

\subsection{Sistem Informasi Manajemen}

Sistem informasi pada dasarnya terbentuk melalui suatu kelompok kegiatan operasional yang tetap dan rutin seperti mengumpulkan data, mengelempokkan data, menghitung data, menganalisa data dan menyajikan laporan. Sistem informasi merupakan sistem yang berisi jaringan Sistem Pengolahan Data (SPD) dilengkapi dengan kanal-kanal komunikasi yang digunakan dalam sistem organisasi data[14].

Pengertian lain dari sistem informasi menurut Hartono (1999), adalah suatu sistem di dalam suatu organisasi yang merupakan kombinasi dari orang-orang, fasilitas, teknologi, media, prosedur-prosedur dan pengendalian yang ditujukan untuk mendapatkan jalur komunikasi, memproses tipe transaksi rutin, memberi sinyal kepada manajemen terhadap kejadian-kejadian internal dan eksternal serta menyediakan suatu dasar informasi untuk pengambilan keputusan yang tepat [7].

Berdasarkan uraian diatas,peneliti menyimpulkan bahwa sistem informasi adalah kumpulan dari beberapa elemen yang saling berkaitan satu dengan lainnya dalam memproses dan mengolah data sehingga menjadi suatu informasi yang bermanfaat dan memiliki sebuah nilai.

Sistem Informasi Manajemen adalah suatu sistem perencanaan di dalam perusahaan yang melibatkan pengendalian internal seperti pemanfaatan sumber daya, dokumen, teknologi, dan akuntansi manajemen sebagai salah satu strategi dalam bisnis. Pada intinya, sistem informasi manajemen dalam bisnis atau perusahaan bertujuan untuk mengumpulkan, memproses, menyimpan hingga menganalisa informasi dan kemudian disebarkan untuk tujuan yang spesifik. Beberapa pengertian manajemen menurut beberapa ahli[5, 6]:

a. Menurut Fayol (1985), manajemen mengandung gagasan lima fungsi utama yaitu merancang, mengorganisasi, memerintah, mengkoordinasi, dan mengendalikan, sedangkan fungsi manajemen adalah sebagai elemen dasar yang akan selalu ada dan melekat di dalam proses pengaturan yang akan dijadikan acuan oleh manajer dalam melaksanakan kegiatan untuk mencapai tujuan. 
b. Menurut Handoko (2000), manajemen adalah sebuah proses pekerjaan untuk menentukan, menginterpretasikan, dan mencapai tujuan-tujuan organisasi dengan pelaksanaan fungsi-fungsi perencanaan, pengorganisasian, penyusunan personalia, pengarahan, kepemimpinan dan pengawasan.

Apabila dilihat dari beberapa pengertian di atas penulis menyimpulkan bahwa pengertian dari sistem informasi manajemen secara umum adalah suatu sistem yang digunakan untuk proses pengolahan dan juga pengorganisasian data serta informasi yang mempunyai sebuah nilai dan digunakan sebagai pendukung untuk mencapai sebuah fungsi suatu organisasi.Secara fungsional, sistem informasi manajemen sangat dibutuhkan untuk mendukung proses penyampaian informasi sehingga dapat meningkatkan kinerja organisasi dalam melakukan pengolahan data menjadi informasi yang pada akhirnya membantu dalam proses pengambilan keputusan [16].

\subsection{Pendidikan \& Pelatihan}

Pendidikan dan pelatihan adalah suatu usaha untuk memelihara, meningkatkan kemampuan, kapasistas maupun profesionalisme pegawai. Hal tersebut penting karena cara yang digunakan oleh organisasi untuk mempertahankan, menjaga, memelihara pegawai publik dalam organisasi dan sekaligus meningkatkan keahlian para pegawai untuk kemudian dapat meningkatkan kinerjanya [1].

Pendidikan dan pelatihan merupakan kegiatan pendidikan pegawai atau calon pegawai yang berkaitan dengan usaha peningkatan pengetahuan, keterampilan, dan sikap dalam rangka pencapaian tujuan organisasi yang efektif dan efisien guna memenuhi persyaratanpersyaratan jabatan fungsional tertentu [2]. Pendidikan dan pelatihan merupakan sebuah upaya organisasi untuk mengembangkan SDM terutama untuk mengembangkan kemampuan intelektual dan kepribadian manusia. Penggunaan istilah pendidikan dan pelatihan dalam suatu institusi atau organisasi biasa disatukan menjadi diklat. Unit yang menangani diklat pegawai lazim disebut Pusdiklat (Pusat pendidikan dan pelatihan). Diklat dapat dipandang sebagai salah satu bentuk investasi. Oleh karena itu setiap organisasi atau instansi yang ingin berkembang, maka diklat bagi karyawannya harus memperoleh perhatian yang besar [9].

Berdasarkan beberapa definisi dari pendidikan dan pelatihan dari beberapa ahli di atas, maka peneliti dapat menyimpulkan bahwa pendidikan dan pelatihan merupakan sebuah kegiatan yang dilakukan dengan tujuan untuk pengembangan kemampuan kerja bagi individu yang berkaitan dengan perusahaan dengan tujuan membantu meningkatkan keterampilan, serta sikap seseorang yang diperlukan oleh perusahaan dalam pencapaian tujuan.

Tujuan yang diharapkan dari penyelenggara pendidikan dan pelatihan bagi suatu perusahaan meliputi[12] :

a. Peningkatan keahlian kerja.

b. Pengurangan keterlambatan, kemangkiran, serta perpindahan. c. Pengurangan timbulnya kecelakaan dalam bekerja, kerusakan dan peningkatan dalam pemeliharaan terhadap alat - alat kerja.

d. Peningkatan produktivitas kerja.

e. Peningkatan kecakapan kerja.

f. Peningkatan rasa tanggung jawab.

\subsection{Metode Servqual}

Metode Servqual merupakan sebuah metode yang digunakan untuk mengukur sebuah kualitas layanan jasa termasuk layanan informasi berdasarkan beberapa faktor atau dimensi, sehingga akan diperoleh nilai gap atau kesenjangan yang merupakan selisih antara persepsi konsumen terhadap layanan yang telah diterima dengan harapan terhadap yang akan diterima.

Metode Service Quality atau sering disingkat Servqualmerupakan sebuah metode yang digunakan untuk mengukur penilaian dari konsumen mengenai keunggulan secara keseluruhan dari sebuah layanan [17].Parasuraman (1990) mendefinisikan 5 (lima) gap yang dapat diidentifikasi sebagai faktor penentu kualitas dari sebuah layanan sebagaimana gambar 1 berikut [10].

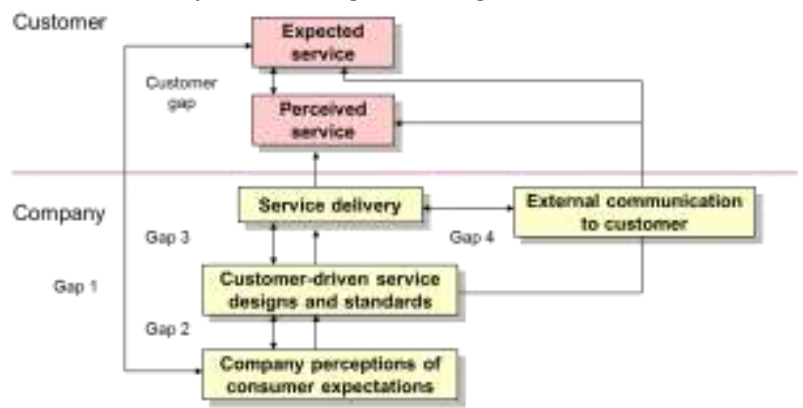

Gambar 1. Gap Kualitas Layanan[10]

Pada metode Servqual, terdapat lima gap yang dapat diidentifikasi sebagai faktor penentu kualitas dari sebuah layanan, antara lain [10]:

a. Gap antara harapan konsumen dan persepsi manajemen. Pada umumnya pihak manajemen sebuah perusahaan tidak selalu dapat merasakan atau memahami apa yang diinginkan oleh para pelanggan secara tepat. Hal tersebut mengakibatkan pihak manajemen kurang mengetahui harus seperti apa desain dari layanan atau jasa yang tepat untuk konsumen.

b. Gap antara persepsi manajemen terhadap harapan konsumen dan spesifikasi kualitas jasa. Terkadang pihak manajemen cukup mampu memahami apa yang diinginkan oleh konsumen, namun kurang dalam penyusunan standar kinerja secara jelas. Hal tersebut mengakibatkan kurangnya kualitas jasa yang diberikan.

c. Gap antara spesifikasi kualitas jasa dan penyampaian jasa. Walaupun perusahaan sudah memiliki spesifikasi kualitas jasa yang baik, terkadang beberapa faktor berikut masih dapat menyebabkan kurangnya kualitas penyampaian jasa, antara lain pihak karyawan yang kurang terlatih, beban kerja yang terlalu banyak, kurangnya sumber daya, atau karena adanya pihak yang tidak ingin mematuhi standard yang telah diberikan. 
Erwin Yulianto ${ }^{1}$,Arief Ginanjar ${ }^{2}$, Pembangunan Sistem Informasi Manajemen Diklat Menggunakan Metode Servqual Dalam Upaya Meningkatkan Kualitas Pelayanan Informasi (Studi Kasus: Balai Diklat Metrologi)

d. Gap antara penyampaian jasa dan komunikasi eksternal. Seringkali harapan pelanggan dipengaruhi oleh iklan dan pernyataan atau janji yang telah dibuat oleh perusahaan. Kewajiban yang dimiliki oleh perusahaan adalah untuk memenuhi janji yang telah diberikan tersebut dan beresiko tidak dapat memenuhi janji tersebut.

e. Gap antara jasa yang dirasakan dan jasa yang diharapkan oleh konsumen. Gap ini terjadi apabila pelanggan mengukur kinerja atau prestasi perusahaan dengan cara lain, atau bisa juga keliru mempersepsikan kualitas jasa tersebut. [4]

\subsection{Kualitas Layanan Informasi}

Kualitas layanan atau service quality dapat didefinisikan sebagai seberapa jauh perbedaan antara kenyataan dan harapan para pelanggan atas layanan yang mereka peroleh atau terima[3]. Menurut Wyckof (Lovelock, 1988), kualitas layanan dapat didefinisikan sebagai Tingkat keunggulan yang diharapkan dan pengendalian atas tingkat keunggulan tersebut untuk memenuhi keinginan pelanggan [15].

Dari definisi diatas, maka peneliti menyimpulkan bahwa kualitas pelayanan informasi sebagai sebuah cara atau proses usaha untuk memenuhi kebutuhan informasi dari konsumen yang disertai dengan ketepatan dalam menyampaikannya, sehingga tercipta kesesuaian yang seimbang dengan apa yang diharapkan oleh konsumen.

Kriteria penilaian yang digunakan pengguna jasa untuk kualitas pelayanan terbagi ke dalam 10 dimensi umum yang dapat mewakili yaitu [10] :

a. Tangibles, yaitu penampilan fisik dari peralatan yang ada.

b. Reliability, yaitu kemampuan untuk menyediakan layanan yang dijanjikan dengan tepat.

c. Responsiveness, yaitu kemampuan untuk menyediakan tanggapan yang cepat pada konsumen atas layanan yang ada.

d. Competence, yaitu tingkat pengetahuan atau keterampilan dalam menyediakan layanan yang diberikan.

e. Courtesy, yaitu tingkat sikap hormat atau juga keramahan yang ditunjukkan pada saat memberikan layanan.

f. Credibility, yaitu tingkat kepercayaan dari konsumen yang diberikan pada penyedia layanan.

g. Security, yaitu tingkat keamanan yang dapat diberikan kepada konsumen pada saat menyediakan layanan.

h. Access, yaitu tingkat kemudahan konsumen dalam menjangkau atau menghubungi penyedia layanan.

i. Communication, yaitu tingkat kemampuan berkomunikasi dari penyedia layanan.

j. Understandingthe Customer, yaitu tingkat pengetahuan penyedia layanan akan kebutuhan dan juga keinginan dari konsumen.

\section{Metode Penelitian}

Dalam melaksanakan penelitian, untuk mendapatkan hasil yang baik, digunakan metode deskriptif dalam pengumpulan data yaitu melalui wawancara, observasi lapangan secara langsung di Balai Diklat Metrologi, studi literatur, dan browsing internet.

Selanjutnya model pengembangan sistem yang digunakan yaitu model Evolutionary Prototype sebagaimana Gambar 2 dengan tahapan-tahapan sebagai berikut [13]:

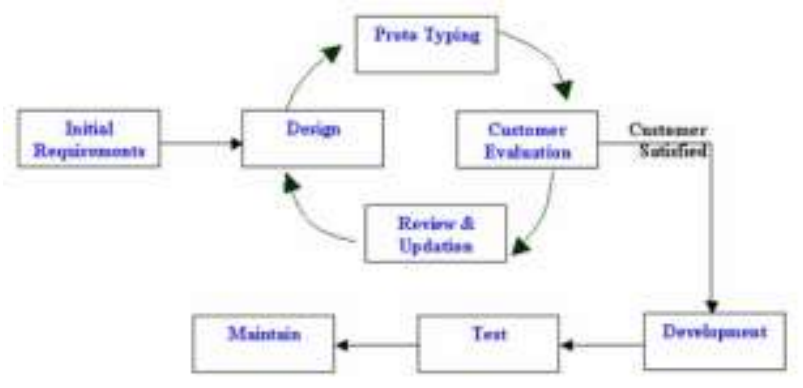

Gambar 2. Evolutionary Prototype [13]

a. Identifikasi persyaratan dasar, meskipun tim peneliti mungkin tidak dapat mengetahui semua persyaratan karena merupakan proses yang berkelanjutan, minimal kita harus dapat mengidentifikasi hal-hal dasar yang diperlukan agar proyek ini dapat mulai berjalan.

b. Membuat prototype, akan ada beberapa prototype yang akan dibuat di dalam proyek ini, dimana masing-masing prototype lebih baik daripada sebelumnya untuk memastikan keberhasilannya.

c. Verifikasi prototype, hal ini dilakukan melalui survei dan eksperimen menggunakan peserta yang diambil dari target pasar. Pengguna adalah orangorang terbaik yang akan dimintakan umpan balik untuk mengetahui apakah sistem yang sudang dikembangkan berfungsi baik atau tidak.

d. Perubahan prototype, ketika ditemukan bahwa prototype dipandang tidak memadai atau tidak memuaskan, tim proyek akan kembali membuat iterasi lebih lanjut sampai dengan aplikasi menjadi sempurna, sesuai umpan balik dari pengguna.

Berdasarkan hasil pengumpulan data, diperoleh analisa proses bisnis dengan menggunakan flow chart, sementaraalat bantu analisis dan perancangan Sistem Informasi Manajemen Diklat yang digunakan yaitu Diagram Unified Modelling Language.

\section{Hasil dan Pembahasan}

\subsection{Proses Bisnis}

Berdasarkan hasil pengumpulan data, diperoleh identifikasi proses bisnis utama yang akan dikonversi ke dalam Sistem Informasi Manajemen Diklat sebagaimana flowmap pada gambar 3 dan 4 sebagai berikut. 


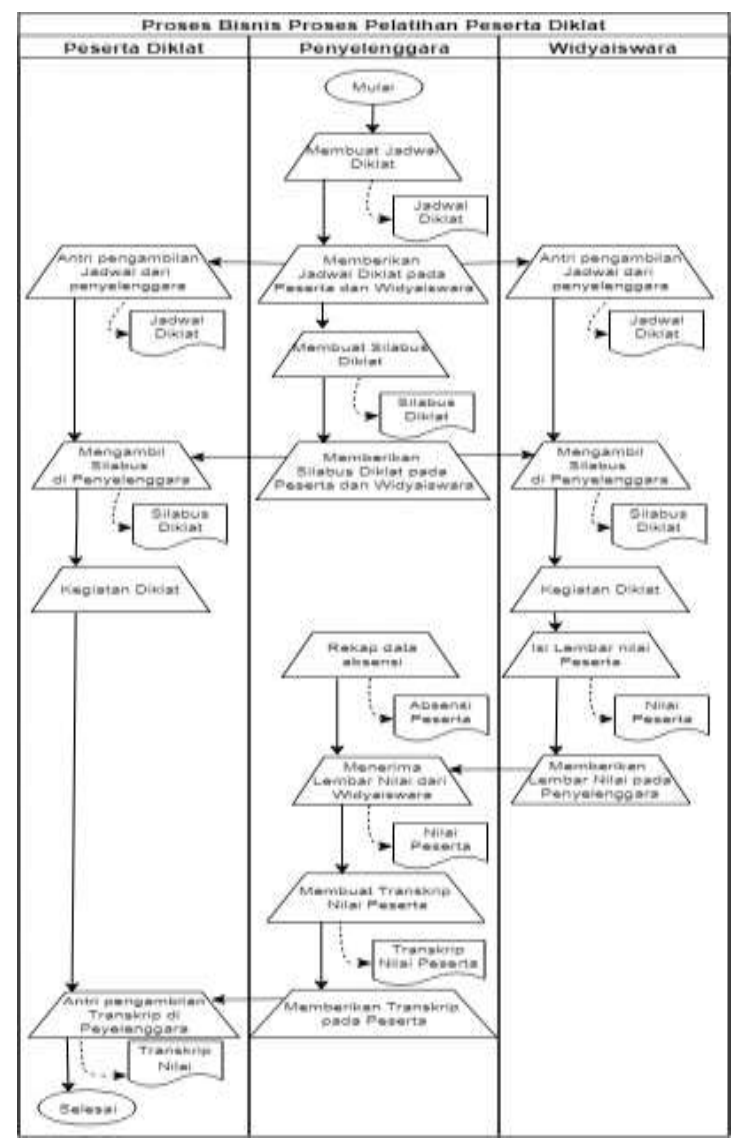

Gambar 3. Proses Bisnis Yang Berjalan

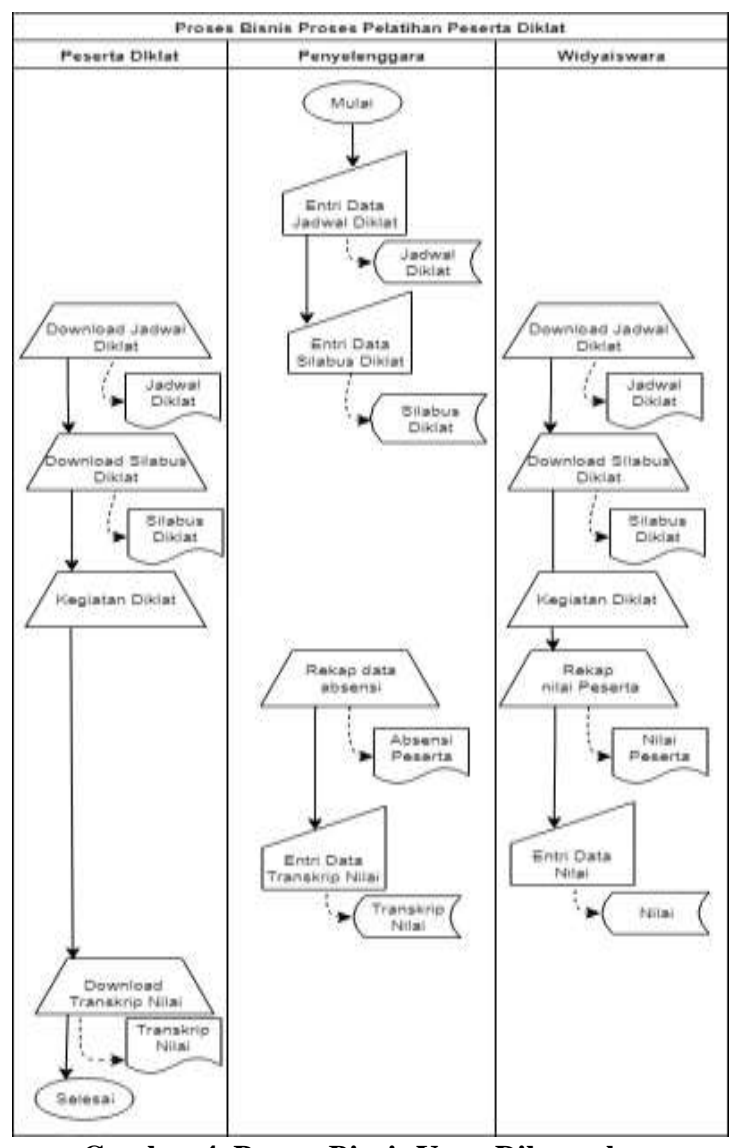

Gambar 4. Proses Bisnis Yang Diharapkan

\subsection{Analisis Kebutuhan Sistem}

Analisis kebutuhan sistem yang akan dikembangkan menjelaskan suatu kondisi atau fungsional yang harus dipenuhi oleh sistem informasi manajemen diklatyang akan dikembangkan sesuai dengan spesifikasi yang diperlukan oleh pengguna. Berdasarkan hasil pengumpulan data, kebutuhan sistem yang dibutuhkan oleh pengguna dapat dilihat sebagai berikut:

1. Analisis Pengguna :

Kategori pengguna yang akan memanfaatkan sistem informasi manajemen diklat, antara lain :

a. Admin : pengguna yang memiliki hak akses penuh dari Sistem Informasi Manajemen Diklat

b. Widyaiswara : pengguna yang terdiri atas para pengajar di Balai Diklat Metrologi (Pengamat Tera, Penera Berjenjang Tingkat Dasar, Penera Berjenjang Tingkat Lanjutan, Penera Kelas A, Penera Kelas B)

c. Penyelenggara Diklat : pengguna yang terdiri dari pranata laboratorium, analis kepegawaian, sekretariatan, pranata komputer

d. Peserta Diklat : pengguna yang merupakan peserta diklat

e. Pengguna Umum

2. Kebutuhan Informasi :

Berikut Tabel 1 menerangkan tentang kebutuhan informasi yang dibutuhkan oleh para pengguna di Balai Diklat Metrologi:

Tabel 1 Analisis Kebutuhan Informasi

\begin{tabular}{|c|l|l|}
\hline No & Kebutuhan Informasi & \multicolumn{1}{c|}{ Pengguna } \\
\hline 1 & Pengumuman & SemuaPengguna \\
\hline 2 & Galeri & SemuaPengguna \\
\hline 3 & $\begin{array}{l}\text { Diklat } \\
\text { a. Kurikulum Diklat } \\
\text { b. Materi Diklat } \\
\text { c. Silabus }\end{array}$ & $\begin{array}{l}\text { Penyelenggara Diklat } \\
\text { Widyaiswara } \\
\text { Peserta Diklat }\end{array}$ \\
\hline 4 & Jadwal Diklat & SemuaPengguna \\
\hline 5 & Pengajar & Penyelenggara Diklat \\
\hline 6 & Penyelenggara Diklat & $\begin{array}{l}\text { Penyelenggara Diklat } \\
\text { Peserta Diklat }\end{array}$ \\
\hline 7 & Peserta Diklat & $\begin{array}{l}\text { Penyelenggara Diklat } \\
\text { Widyaiswara } \\
\text { Peserta Diklat }\end{array}$ \\
\hline 8 & Hasil Diklat & Semua Pengguna \\
\hline 9 & Buku Tamu & Semua Pengguna \\
\hline 10 & Ruang Diklat & \multicolumn{2}{|l}{} \\
\hline
\end{tabular}

3. Kebutuhan Fungsional Sistem Informasi Manajemen Diklat :

Berikut tabel 2 menerangkan tentang kebutuhan fungsional aplikasi yang dibutuhkan oleh para pengguna:

Tabel 2 Analisis Kebutuhan Fungsional

\begin{tabular}{|c|l|l|l|}
\hline No & \multicolumn{1}{|c|}{$\begin{array}{c}\text { Kebutuhan } \\
\text { Fungsional }\end{array}$} & \multicolumn{1}{|c|}{ Pengguna } & Deskripsi \\
\hline 1 & Kelola Master & Admin & CRUD \\
& Pengumuman & Penyelenggara Diklat & CRU \\
& & Widyaiswara & R \\
& & Peserta Diklat & R \\
\hline 2 & Kelola Master & Admin & CRUD \\
& Galeri & Penyelenggara Diklat & CRU \\
& & Widyaiswara & R \\
& & Peserta Diklat & R \\
\hline
\end{tabular}


Erwin Yulianto ${ }^{1}$,Arief Ginanjar ${ }^{2}$, Pembangunan Sistem Informasi Manajemen Diklat Menggunakan Metode Servqual Dalam Upaya Meningkatkan Kualitas Pelayanan Informasi (Studi Kasus: Balai Diklat Metrologi)

\begin{tabular}{|c|c|c|c|}
\hline No & $\begin{array}{l}\text { Kebutuhan } \\
\text { Fungsional }\end{array}$ & Pengguna & Deskripsi \\
\hline 3 & $\begin{array}{l}\text { Kelola Master } \\
\text { Diklat } \\
\text { (Kurikulum, } \\
\text { Materi, Silabus) }\end{array}$ & $\begin{array}{l}\text { Admin } \\
\text { Penyelenggara Diklat } \\
\text { Widyaiswara } \\
\text { Peserta Diklat }\end{array}$ & $\begin{array}{l}\text { CRUD } \\
\text { CRU } \\
\text { CRU } \\
\mathrm{R}\end{array}$ \\
\hline 4 & $\begin{array}{l}\text { Kelola Master } \\
\text { Jadwal Diklat }\end{array}$ & $\begin{array}{l}\text { Admin } \\
\text { Penyelenggara Diklat } \\
\text { Widyaiswara } \\
\text { Peserta Diklat }\end{array}$ & $\begin{array}{l}\text { CRUD } \\
\text { CRU } \\
\mathrm{R} \\
\mathrm{R}\end{array}$ \\
\hline 5 & $\begin{array}{l}\text { Kelola Master } \\
\text { Pengajar }\end{array}$ & $\begin{array}{l}\text { Admin } \\
\text { Penyelenggara Diklat } \\
\text { Widyaiswara } \\
\text { Peserta Diklat }\end{array}$ & $\begin{array}{l}\text { CRUD } \\
\text { R } \\
\text { RU } \\
\text { R }\end{array}$ \\
\hline 6 & $\begin{array}{l}\text { Kelola Master } \\
\text { Penyelenggara } \\
\text { Diklat }\end{array}$ & $\begin{array}{l}\text { Admin } \\
\text { Penyelenggara Diklat }\end{array}$ & $\begin{array}{l}\text { CRUD } \\
\text { RU }\end{array}$ \\
\hline 7 & $\begin{array}{l}\text { Kelola Master } \\
\text { Peserta Diklat }\end{array}$ & $\begin{array}{l}\text { Admin } \\
\text { Penyelenggara Diklat } \\
\text { Peserta Diklat }\end{array}$ & $\begin{array}{l}\text { CRUD } \\
\text { R } \\
\text { RU }\end{array}$ \\
\hline 8 & $\begin{array}{l}\text { Kelola Master } \\
\text { Hasil Diklat }\end{array}$ & $\begin{array}{l}\text { Admin } \\
\text { Penyelenggara Diklat } \\
\text { Widyaiswara } \\
\text { Peserta Diklat }\end{array}$ & $\begin{array}{l}\text { CRUD } \\
\text { CRU } \\
\text { CRU } \\
\mathrm{R}\end{array}$ \\
\hline 9 & $\begin{array}{l}\text { Kelola } \quad \text { Buku } \\
\text { Tamu }\end{array}$ & $\begin{array}{l}\text { Admin } \\
\text { Penyelenggara Diklat } \\
\text { Widyaiswara } \\
\text { Peserta Diklat }\end{array}$ & $\begin{array}{l}\text { CRUD } \\
\text { CR } \\
\text { CR } \\
\text { CR }\end{array}$ \\
\hline 10 & $\begin{array}{ll}\text { Kelola } & \text { Ruang } \\
\text { Diklat } & \end{array}$ & $\begin{array}{l}\text { Admin } \\
\text { Penyelenggara Diklat } \\
\text { Widyaiswara } \\
\text { Peserta Diklat }\end{array}$ & $\begin{array}{l}\text { CRUD } \\
\text { CRU } \\
\mathrm{R} \\
\mathrm{R}\end{array}$ \\
\hline
\end{tabular}

\subsection{Penerapan Metode Service Quality (Servqual)}

Berikut tabel 4 menerangkan tentang kebutuhan fungsional terkait penerapan metode Servqual pada Sistem Informasi Manajemen Diklat yang dibutuhkan oleh para pengguna:

Tabel 4 Analisis Penerapan Metode Servqual

\begin{tabular}{|c|c|c|c|}
\hline No & $\begin{array}{l}\text { Kebutuhan } \\
\text { Informasi }\end{array}$ & Gap & Deskripsi \\
\hline \multirow[b]{2}{*}{1} & \multirow[b]{2}{*}{ Pengumuman } & 3 & $\begin{array}{l}\text { Isi pengumuman yang detail atas } \\
\text { isi yang akan disampaikan, } \\
\text { ditambahkan dengan } \\
\text { foto/gambar serta info detail. }\end{array}$ \\
\hline & & 4 & $\begin{array}{l}\text { Memberikan info tambahan } \\
\text { berupa tanggal deadline jika isi } \\
\text { pengumuman tersebut } \\
\text { membutuhkan tindak lanjut dari } \\
\text { pengguna }\end{array}$ \\
\hline \multirow{3}{*}{2} & \multirow{3}{*}{ Galeri } & 2 & $\begin{array}{l}\text { Penggunaan fitur feedback pada } \\
\text { gambar yang ada pada galeri } \\
\text { untuk menampung komentar } \\
\text { pengguna terkait gambar pada } \\
\text { galeri tersebut baik kesesuaian } \\
\text { antara gambar dan realita } \\
\text { ataupun jika terdapat kesalahan } \\
\text { informasi yang kurang jelas / } \\
\text { belum disampaikan. }\end{array}$ \\
\hline & & 4 & $\begin{array}{l}\text { Pemberian check boxReview } \\
\text { pada tiap gambar di galeri } \\
\text { sebagai alat kontrol bagi admin } \\
\text { yang berfungsi sebagai } \\
\text { pengecekan oleh pengguna } \\
\text { apakah galeri tersebut masih } \\
\text { relevan dengan kondisi saat ini } \\
\text { atau perlu diperbaharui. }\end{array}$ \\
\hline & & 5 & $\begin{array}{l}\text { Pemberian informasi detil pada } \\
\text { setiap gambar di menu galeri. }\end{array}$ \\
\hline \multirow[t]{2}{*}{3} & \multirow{2}{*}{$\begin{array}{l}\text { Diklat } \\
\text { a. Kurikulum } \\
\text { Diklat } \\
\text { b. Materi }\end{array}$} & 3 & $\begin{array}{l}\text { Penyampaian materi diklat dan } \\
\text { silabus dengan kurikulum } \\
\text { terbaru. }\end{array}$ \\
\hline & & 4 & Ditambahkan informasi terkait \\
\hline
\end{tabular}

\begin{tabular}{|c|c|c|c|}
\hline No & $\begin{array}{l}\text { Kebutuhan } \\
\text { Informasi }\end{array}$ & Gap & Deskripsi \\
\hline & $\begin{array}{ll} & \text { Diklat } \\
\text { c. } & \text { Silabus }\end{array}$ & & $\begin{array}{l}\text { kesesuaian kurilum dengan } \\
\text { kebutuhan di dunia industri }\end{array}$ \\
\hline & & 5 & $\begin{array}{l}\text { Penggunaan informasi detil } \\
\text { terkait dengan data materi diklat } \\
\text { seperti jumlah bab, jurusan } \\
\text { terkait, dan juga penjelasan } \\
\text { singkat materi. }\end{array}$ \\
\hline \multirow{3}{*}{4} & \multirow{3}{*}{ Jadwal Diklat } & 1 & $\begin{array}{l}\text { Penyesuaian jadwal secara } \\
\text { fleksibel (beberapa alternatif) } \\
\text { jika terdapat ketidaksesuaian } \\
\text { antara jadwal diklat dengan } \\
\text { kesesuaian waktu yang dimiliki } \\
\text { oleh peserta diklat }\end{array}$ \\
\hline & & 2 & $\begin{array}{l}\text { Penyampaian informasi standar } \\
\text { jadwal untuk setiap materi diklat } \\
\text { dilengkapi dengan kurikulum } \\
\text { dan silabus }\end{array}$ \\
\hline & & 3 & $\begin{array}{l}\text { Penyampaian informasi standar } \\
\text { jadwal yang jelas dilengkapi } \\
\text { dengan data pengajar, materi } \\
\text { diklat, informasi ruang kelas / } \\
\text { lab, waktu pelaksanaan, dan } \\
\text { jumlah jam teoripraktek yang } \\
\text { harus ditempuh untuk } \\
\text { memaksimalkan standar layanan } \\
\text { dalam kegiatan belajar mengajar. }\end{array}$ \\
\hline \multirow[t]{2}{*}{5} & \multirow[t]{2}{*}{ Pengajar } & 2 & $\begin{array}{l}\text { Penyampaian data latar belakang } \\
\text { pendidikan pengajar dan } \\
\text { pengalaman mengajar sebagai } \\
\text { referensi bagi peserta diklat } \\
\text { tentang kualitas pengajar }\end{array}$ \\
\hline & & 5 & $\begin{array}{l}\text { Memberikan beberapa informasi } \\
\text { seperti daftar prestasi yang } \\
\text { dimiliki oleh para pengajar Balai } \\
\text { Diklat Metrologi }\end{array}$ \\
\hline 6 & $\begin{array}{l}\text { Penyelenggara } \\
\text { Diklat }\end{array}$ & 3 & $\begin{array}{l}\text { Berisi informasi jelas tentang } \\
\text { penyelenggara diklat, tugas } \\
\text { pokok, fungsi dan tanggung } \\
\text { jawabnya }\end{array}$ \\
\hline \multirow[t]{2}{*}{7} & \multirow[t]{2}{*}{ Peserta Diklat } & 1 & $\begin{array}{l}\text { Sistem Informasi Manajemen } \\
\text { Diklat dilengkapi dengan fitur } \\
\text { slef service bagi para peserta } \\
\text { diklat untuk melakukan } \\
\text { pemilihan jenis diklat, registrasi, } \\
\text { dan fungsi-fungsi lainnya }\end{array}$ \\
\hline & & 3 & $\begin{array}{l}\text { Penyediaan rekomendasi silabus } \\
\text { yang sesuai dengan diklat } \\
\text { peserta. }\end{array}$ \\
\hline 8 & Hasil Diklat & 1 & $\begin{array}{l}\text { Sebelum menampilkan hasil } \\
\text { diklat, sistem informasi } \\
\text { manajemen diklat dilengkapi } \\
\text { dengan fitur pengisian kuisioner } \\
\text { dan feedback dari peserta diklat } \\
\text { akan kualitas dari materi dan } \\
\text { pengajar sebagai bahan evaluasi } \\
\text { penyelenggara diklat }\end{array}$ \\
\hline 9 & Buku Tamu & 1 & $\begin{array}{l}\text { Penggunaan kolom kritik dan } \\
\text { saran pada fungsional buku tamu } \\
\text { agar Balai Diklat Metrologi } \\
\text { dapat lebih memahami apa yang } \\
\text { diinginkan oleh pengguna. }\end{array}$ \\
\hline 10 & Ruang Diklat & 5 & $\begin{array}{l}\text { Memberikan info detail } \\
\text { mengenai ruang diklat, kapasitas } \\
\text { peserta, jenis-jenis ruang diklat } \\
\text { dan peralatan-peralatan simulasi } \\
\text { yang dimiliki di laboratorium } \\
\text { diklat }\end{array}$ \\
\hline
\end{tabular}

\subsection{Analisis Pemodelan Fungsional}

Analisis kebutuhan sistem yang akan dikembangkan menjelaskan suatu kondisi atau fungsional yang harus dipenuhi oleh sistem, dalam hal ini akan menggunakan Unified Modelling Language (UML) sebagai berikut : 


\section{Use Case Diagram}

Penggunaan Use Case Diagram akan menggambarkan interaksi aktor dengan sistem yang berjalan, selain itu juga dapat menggambarkan fungsional dari aplikasi. Adapun Use Case Diagram untuk front end dan back end dari Sistem Informasi Manajemen Diklat dengan menggunakan metode Servqual dapat dilihat pada Gambar 5 dan 6 berikut.

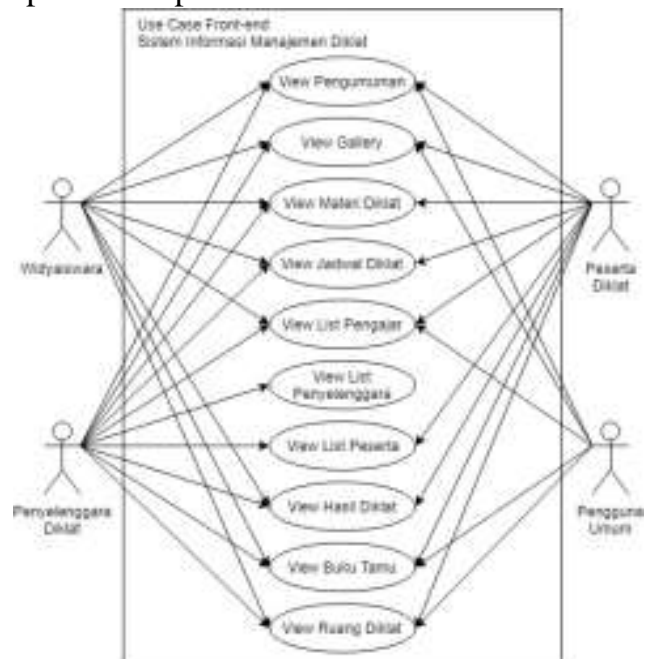

Gambar 5. Use Case Diagram Front-End

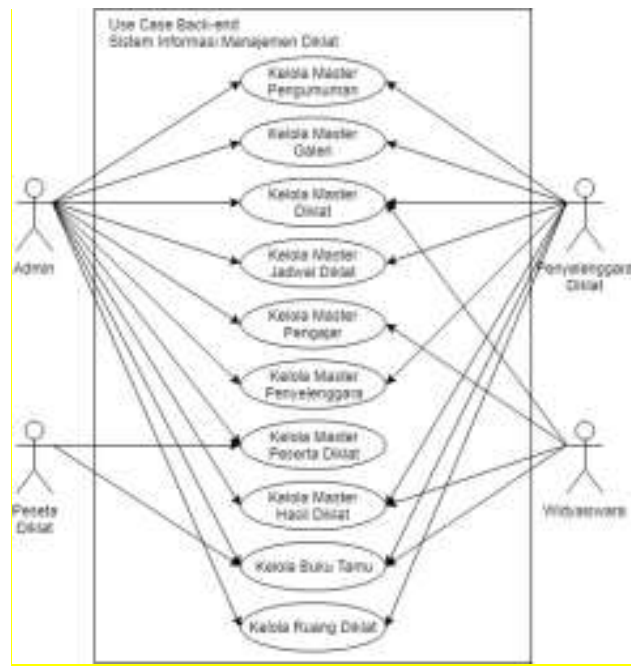

Gambar 6. Use Case Diagram Back-End

\section{Class Diagram}

Penggunaan Class Diagram diharapkan dapat menggambarkan hubungan antar kelas di dalam sistem dan juga penjelasan atribut dari tiap kelas yang ada pada sistem. Dengan diagram ini diharapkan juga dapat memberi gambaran mengenai aturan dan juga fungsi dari tiap entitas yang menentukan perilaku sistem. Rancangan Class Diagram dari sistem ini dapat dilihat pada Gambar 7 sebagai berikut.

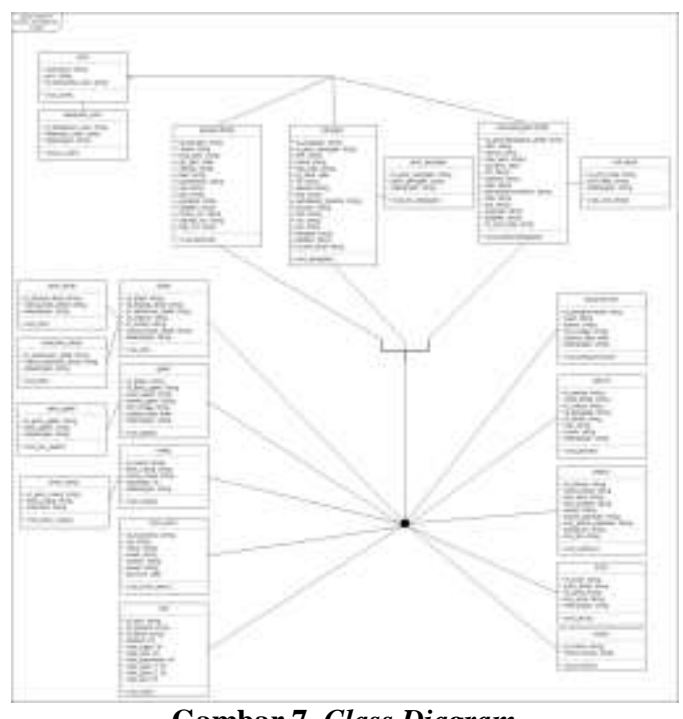

Gambar 7. Class Diagram

\subsection{Perancangan Basis Data}

Perancangan basis data yang akan digunakan dalam Sistem Informasi Manajemen Diklat ini dapat dilihat pada tabel 5 berikut:

\section{Tabel 5 Perancangan Basis Data}

\begin{tabular}{|c|c|c|}
\hline No & Nama Tabel & Fields \\
\hline 1 & Pengumuman & $\begin{array}{l}\text { ID_Pengumuman }(\mathrm{PK}), \quad \text { Judul, } \\
\text { Narasi, } \\
\text { Tanggal_Upload, Keterangan }\end{array}$ \\
\hline 2 & Galeri & $\begin{array}{l}\text { ID_Galeri (PK), ID_Jenis_Galeri } \\
\text { (FK), Judul_Galeri, Narasi_Galeri, } \\
\text { Link_Image, Tanggal_Upload, } \\
\text { Keterangan }\end{array}$ \\
\hline 3 & Jenis_Galeri & $\begin{array}{l}\text { ID_Jenis_Galeri, Jenis_Galeri, } \\
\text { Keterangan }\end{array}$ \\
\hline 4 & Diklat & $\begin{array}{l}\text { ID_Diklat (PK), ID_Tingkat_Diklat } \\
\text { (FK), ID_Kelompok_Diklat (FK), } \\
\text { ID_Silabus (FK), ID_Modul (FK) }\end{array}$ \\
\hline 5 & Jenis_Diklat & $\begin{array}{l}\text { ID_Tingkat_Diklat (PK), } \\
\text { Nama_Jenis_Diklat, Keterangan }\end{array}$ \\
\hline 6 & Kelompok_Diklat & $\begin{array}{l}\text { ID_Kelompok_Diklat } \\
\text { Nama_Kelompok_Diklat, } \\
\text { Keterangan }\end{array}$ \\
\hline 7 & Modul & ID_Modul (PK), Nama_Modul \\
\hline 8 & Silabus & $\begin{array}{l}\text { ID_Silabus (PK), Nama_Diklat, } \\
\text { Jam_Teori, Jam_Praktek, Tujuan, } \\
\text { Pokok_Bahasan, } \\
\text { Sub_Pokok_Bahasan, Praktikum, } \\
\text { Link_File }\end{array}$ \\
\hline 9 & Jadwal & $\begin{array}{l}\text { ID_Jadwal (PK), Kode_Diklat (FK), } \\
\text { ID_Ruang (FK), ID_Pengajar (FK), } \\
\text { ID_Diklat (FK), Hari, Waktu, } \\
\text { Keterangan }\end{array}$ \\
\hline 10 & Pengajar & $\begin{array}{l}\text { ID_Pengajar }(\mathrm{PK}) \text {, } \\
\text { ID_Jenis_Pengajar (FK), NIP , } \\
\text { Nama,Tmp_Lahir, Tgl_Lahir, JK, } \\
\text { Alamat, Telp, Pendidikan_Terakhir, } \\
\text { Jurusan, Link_Foto, Gol, Pangkat, } \\
\text { Jabatan, ID_Unit_Kerja (FK) }\end{array}$ \\
\hline 11 & Jenis_Pengajar & $\begin{array}{ll}\text { ID_Jenis_Pengajar } & \text { (PK), } \\
\text { Jenis_Pengajar, Keterangan } & \end{array}$ \\
\hline 12 & Penyelenggara_Diklat & $\begin{array}{l}\text { ID_Penyelenggara_Diklat } \\
\text { (FK), NIP, Nama, Tmp_Lahir, } \\
\text { Tgl_Lahir, JK, Alamat, Telp, } \\
\text { Pendidikan_Terakhir, Link_Foto, } \\
\text { Golongan, Pangkat, Jabatan, } \\
\text { ID_Unit_Kerja (FK) }\end{array}$ \\
\hline 13 & Unit_Kerja & $\begin{array}{l}\text { ID_Unit_Kerja, } \\
\text { Keterangan }\end{array}$ \\
\hline
\end{tabular}


Erwin Yulianto ${ }^{1}$,Arief Ginanjar ${ }^{2}$, Pembangunan Sistem Informasi Manajemen Diklat Menggunakan Metode Servqual Dalam Upaya Meningkatkan Kualitas Pelayanan Informasi (Studi Kasus: Balai Diklat Metrologi)

\begin{tabular}{|c|c|c|}
\hline No & Nama Tabel & Fields \\
\hline 14 & Peserta_Diklat & $\begin{array}{l}\text { ID_Peserta (PK), Nama, } \\
\text { Tempat_Lahir, Tgl_Lahir, Alamat, } \\
\text { Telp, Pendidikan, NIP, Gol, } \\
\text { Pangkat, Jabatan, Nama_Instansi, } \\
\text { Alamat_Instansi, Telp_Instansi }\end{array}$ \\
\hline 15 & Ruang & $\begin{array}{l}\text { ID_Ruang (PK), Jenis_Ruang (FK), } \\
\text { Nama_Ruang, } \\
\text { Keterangan }\end{array}$ \\
\hline 16 & Jenis_Ruang & $\begin{array}{l}\text { ID_Jenis_Ruang, Jenis_Ruang, } \\
\text { Informasi }\end{array}$ \\
\hline 17 & Nilai & $\begin{array}{l}\text { ID_Nilai (PK), ID_Peserta (FK), } \\
\text { ID_Diklat (FK), Absensi, } \\
\text { Nilai_Tugas, } \\
\text { Nilai_Presentasi, Nilai_Quiz, } \\
\text { Nilai_Ujian_2, Nilai_Lain }\end{array}$ \\
\hline 18 & BukuTamu & $\begin{array}{l}\text { ID_BukuTamu (PK), NIP, Nama, } \\
\text { Email, Subjek, Pesan, Tgl_Kirim }\end{array}$ \\
\hline 19 & Arsip & $\begin{array}{l}\text { ID_Arsip (PK), Judul_Arsip, } \\
\text { Isi_Arsip, Link_Arsip, Keterangan }\end{array}$ \\
\hline 20 & User & $\begin{array}{ll}\text { Username } & \text { (PK), } \\
\text { ID_Kelompok_User } & \text { (FK), } \\
\text { Password } & \end{array}$ \\
\hline 21 & Kelompok_User & $\begin{array}{l}\text { ID_Kelompok_User, } \\
\text { Kelompok_User, Keterangan }\end{array}$ \\
\hline
\end{tabular}

\subsection{Perancangan Sitemap}

Sitemap merupakan alat bantu yang mempermudah dalam pengenalan peta situs di dalam Sistem Informasi berbasis web.Perancangan sitemap dari Sistem Informasi Manajemen Diklat ini dapat dilihat pada Gambar 8berikut:

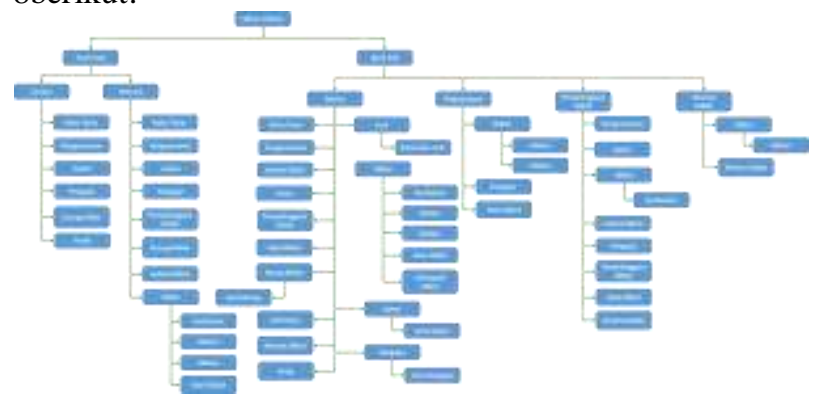

Gambar 8. Sitemap Sistem Informasi Manajemen Diklat

\subsection{Implementasi Antarmuka}

Implementasi antarmuka dari Sistem Informasi Manajemen Diklat ini dibagi menjadi 2 bagian, antara lain:

1. Implementasi Antarmuka Front End, merupakan antarmuka yang digunakan oleh penggunaumum dari sistem informasi manajemen diklat. Implementasi antarmuka dari bagian ini dapat dilihat sebagai berikut :

a) Halaman Utama, merupakan halaman yang pertama kali ditampilkan saat website dibuka. Pada bagian pengumuman terdapat pilihan read more untuk masuk ke Halaman Pengumuman seperti pada Gambar 9. Halaman pengumuman dilengkapi dengan detail atas isi yang disampaikan beserta foto untuk mendukung Servqual Gap 3. Halaman Pengumman juga memiliki info tanggal upload pengumuman sebagai penerapan Servqual Gap4. Tampilan Halaman Utama dan Halaman Pengumuman dapat dilihat pada Gambar 9 dan 10 di bawah ini.

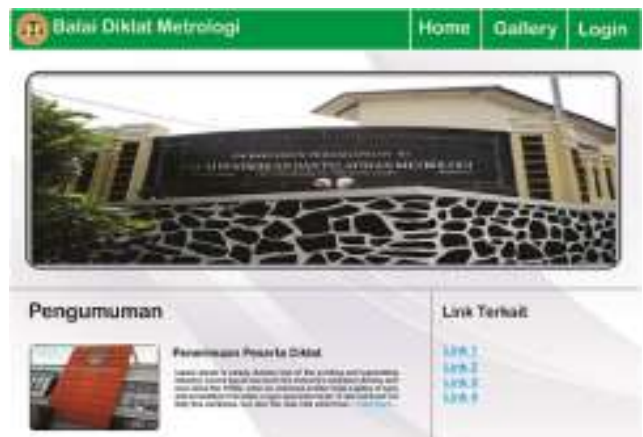

Gambar 9. Halaman Utama

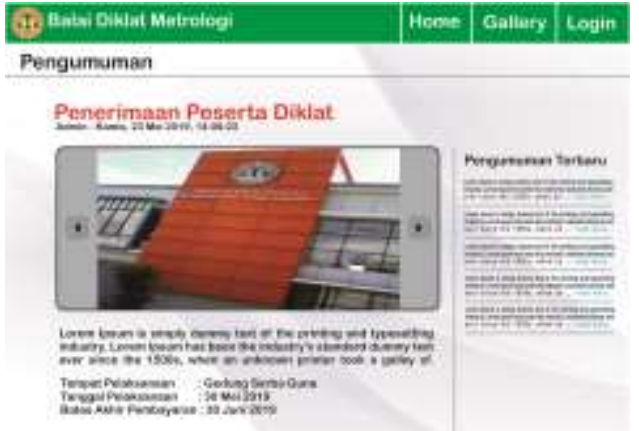

Gambar 10. Halaman Utama

b) Halaman Galeri, merupakan halaman untuk menampilkan foto-foto dari fasilitas, peralatan dan kegiatan lainnya yang difasilitasi oleh Balai Diklat Metrologi. Pada Halaman Galeri pengguna dapat memilih gambar yang diinginakn untuk menampilkan pop up detail mengenai gambar tersebut sebagai penerapan Servqual Gap 5. Selain itu, pada menu Galeri Detail juga terdapat fitur feedback untuk menerapkan Servqual Gap 1 agar pihak admin dapat mengetahui tanggapan user terkait fasilitas tersebut sehingga menjadi masukan bagi Balai Diklat Metrologi. Pemberian fitur check box Reviewdiberikan sebagai alat kontrol bagi admin untuk mengecek kondisi fasilitas tersebut sebagai implementasi Servqual Gap 4. Tampilan Halaman Galeri dapat dilihat pada Gambar 11 dan 12 sebagai berikut.

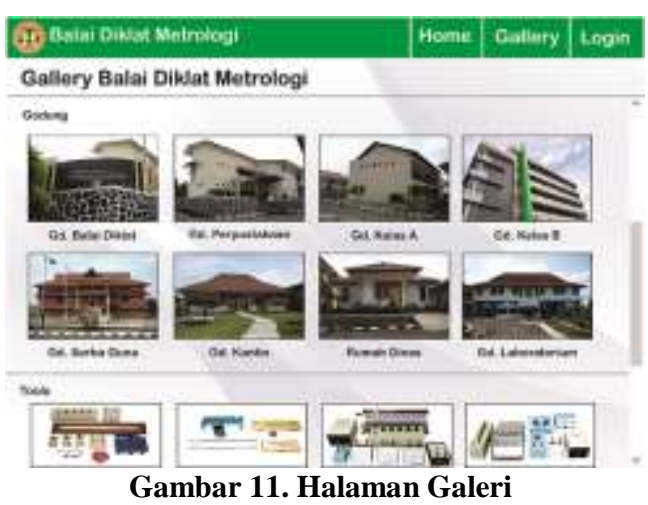




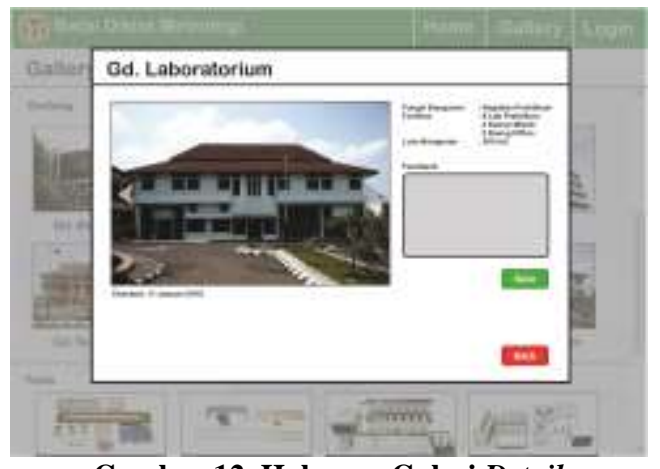

Gambar 12. Halaman Galeri Detail

c) Halaman Diklat, merupakan halaman untuk melihat dan mengunduh kurikulum diklat, materi diklat, dan silabus. Pada Halaman Diklat, penyampaian materi dilengkapi kurikulum terbaru sebagai solusi penerapan Servqual Gap3. Penambahan informasi terkait kesesuaian kurikulum dengan kebutuhan di dunia industri juga dilakukan sebagai solusi Servqual Gap4. Selain itu, penggunaan informasi detil terkait dengan data materi diklat seperti jumlah bab, jurusan terkait, dan penjelasan singkat materi diberikan untuk menanggapi permasalahan padaServqual Gap5. Tampilan Halaman Diklat dapat dilihat pada Gambar 13 berikut.

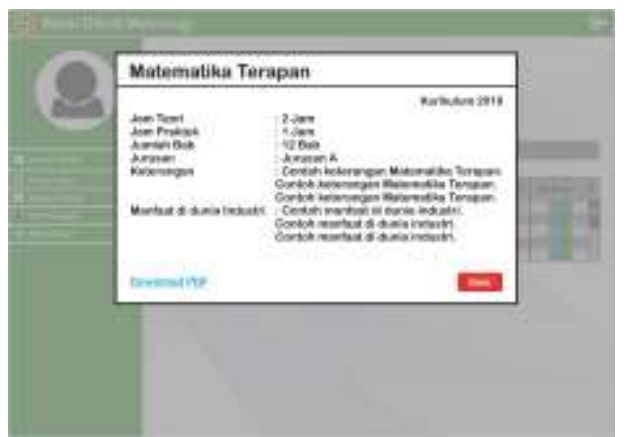

Gambar 13. Halaman Diklat Detail

d) Halaman Peserta, merupakan halaman menu yang hanya dapat diakses oleh peserta diklat yang terdaftar. Halaman ini berisi informasi mengenai rincian data peserta. Pada halaman ini juga disediakan rekomendasi silabus yang sesuai dengan profil diklat peserta untuk menunjang penyelesaian masalah Servqual Gap3. Tampilan Halaman Menu Peserta dapat dilihat pada Gambar 14 di bawah ini.

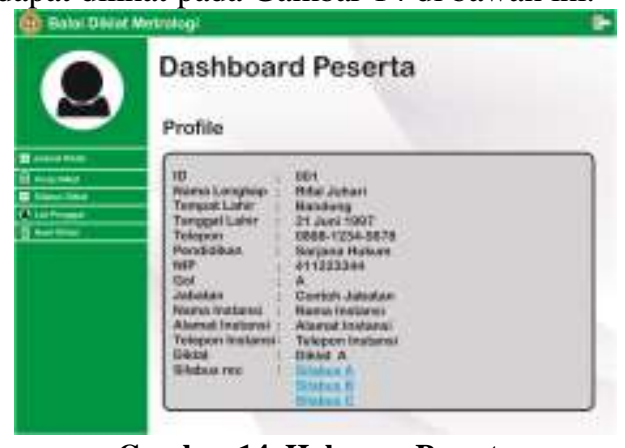

Gambar 14. Halaman Peserta e) Halaman View Jadwal, merupakan halaman untuk melihat daftar jadwal diklat peserta. Penyesuaian jadwal dapat dilakukan secara fleksibel apabila terdapat ketidaksesuaian anatara jadwal diklat dengan waktu yang dimiliki peserta.Fitur ini dapat membantu menyelesaikan permasalahan pada Servqual Gap1. Informasi jadwal dilengkapi dengan kurikulum dan silabus untuk menyelesaikan masalah Servqual Gap2. Penyampaian informasi jadwal juga harus dilakukan secara detail seperti pencantuman informasi ruangan, waktu, pengajar dan lainnya untuk meminimalisasi masalah Servqual Gap3. Tampilan Halaman View Jadwal dapat dilihat pada Gambar 15 di bawah ini.

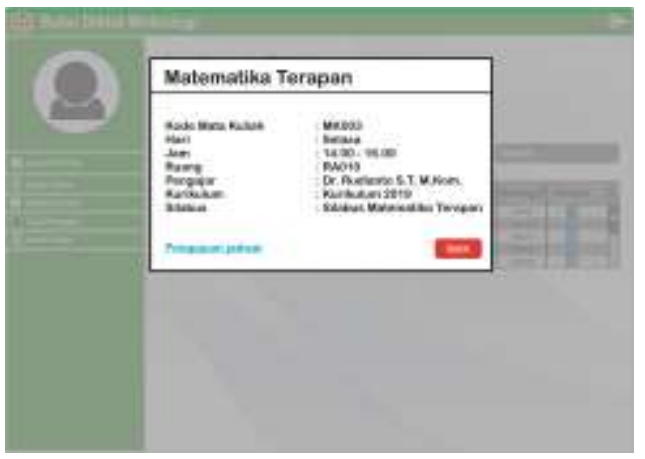

Gambar 15. Halaman View Jadwal

f) Halaman Daftar Pengajar, merupakan halaman untuk melihat daftar pengajar yang terdaftar di Balai Diklat Metrologi. Pada halaman ini disampaikan informasi latar belakang pendidikan pengajar dan pengalaman mengajar sebagai referensi bagi peserta. Hal tersebut mendukung kebutuhan informasi dan menyelesaikan permasalahan Servqual Gap2. Selain itu juga penambahan informasi prestasi yang dimiliki oleh para pengajar sebagai penunjang Servqual Gap5. Tampilan untuk Halaman Daftar Pengajar ini dapat dilihat pada Gambar 16 di bawah ini.

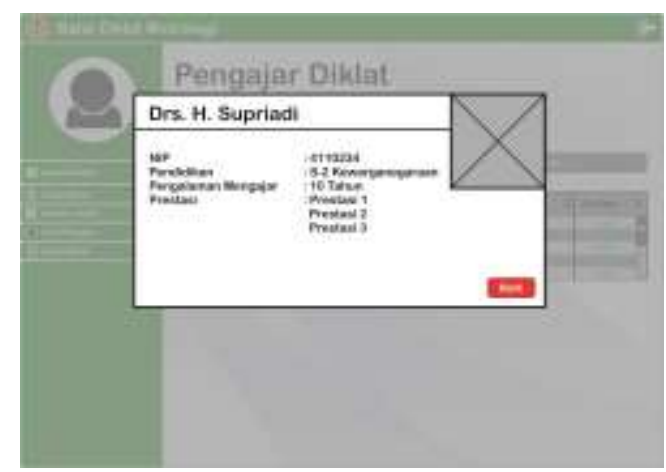

Gambar 16. Halaman Daftar Pengajar

g) Halaman Daftar Penyelenggara Diklat, merupakan halaman untuk melihat daftar penyelenggara Diklat Metrologi. Pada halaman ini berisi informasi jelas tentang informasi penyelenggara diklat, tugas pokok, fungsi dan tanggung jawabnya. Informasi 
Erwin Yulianto ${ }^{1}$,Arief Ginanjar ${ }^{2}$, Pembangunan Sistem Informasi Manajemen Diklat Menggunakan Metode Servqual Dalam Upaya Meningkatkan Kualitas Pelayanan Informasi (Studi Kasus: Balai Diklat Metrologi)

tersebut dibutuhkan untuk menyelesaikan permasalahanServqual Gap3. Tampilan untuk Halaman Daftar Penyelenggara Diklat ini dapat dilihat pada Gambar 17 berikut ini.

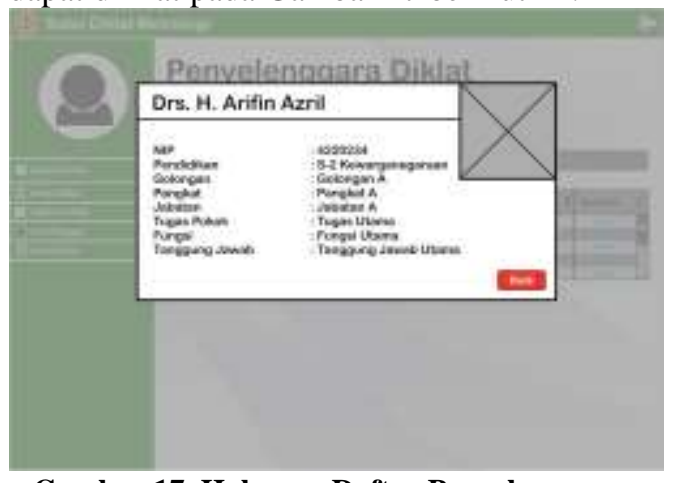

Gambar 17. Halaman Daftar Penyelenggara Diklat

h) Halaman Hasil Diklat, merupakan halaman untuk melihat dan mengunduh transkrip nilai atas hasil diklat yang telah dilaksanakan. Selain menampilkan hasil diklat, halaman ini juga terdapat fitur pengisian kuisioner dan feedback dari peserta diklat akan kualitas dari materi dan pengajar sebagai bahan evaluasi penyelenggara diklat. Fitur tersebut merupakan jawaban atas permasalahan Servqual Gap1. Tampilan Halaman Hasil Diklat ini dapat dilihat pada Gambar 18 di bawah ini.

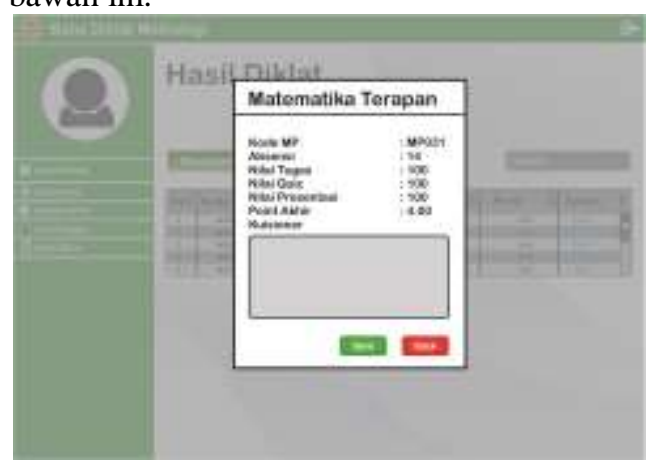

Gambar 18. Halaman Hasil Diklat

i) Halaman Ruang Diklat, merupakan menu untuk melihat daftar ruangan yang terdapat pada Balai Diklat Metrologi. Menu ini memberikan info detail mengenai ruang diklat, kapasitas peserta, jenis ruang diklat dan peralatan simulasi yang dimiliki oleh laboratorium diklat. Informasi tersebut merupakan jawaban atas permasalahan Servqual Gap 5.Tampilan dari Halaman Ruang Diklat dapat dilihat pada Gambar 19 di bawah ini.

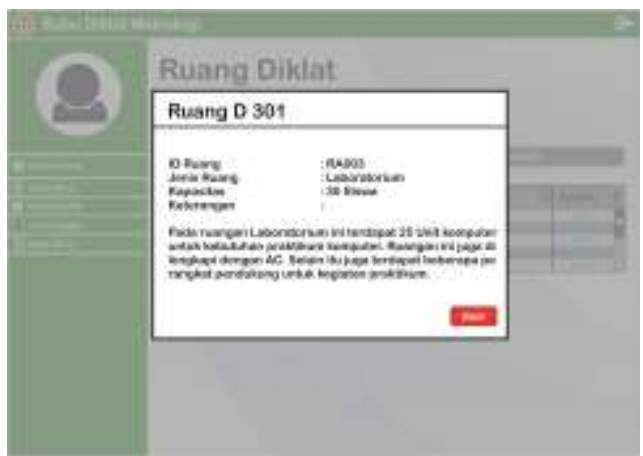

Gambar 19. Halaman Ruang Diklat

2. Implementasi Antarmuka Back End, merupakan antarmuka yang digunakan oleh pihak admin dari Sistem Informasi Manajemen Diklat. Implementasi antarmuka pada bagian Back End dapat dilihat sebagai berikut :

a) Halaman Menu Administrator, merupakan halaman menu yang hanya dapat diakses oleh Admin. Halaman Menu Administratordapat dilihat pada Gambar 21 di bawah ini.

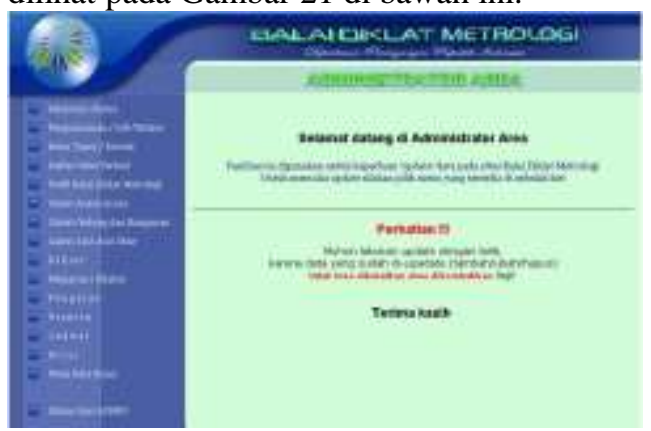

Gambar 21. Halaman Menu Administrator

b) Halaman Kelola Pengumuman, merupakan halaman untuk mengelola data pengumuman untuk kepentingan sosialisasi dan/atau isu terkini. Halaman Kelola Pengumuman dapat dilihat pada Gambar 22 di bawah ini.

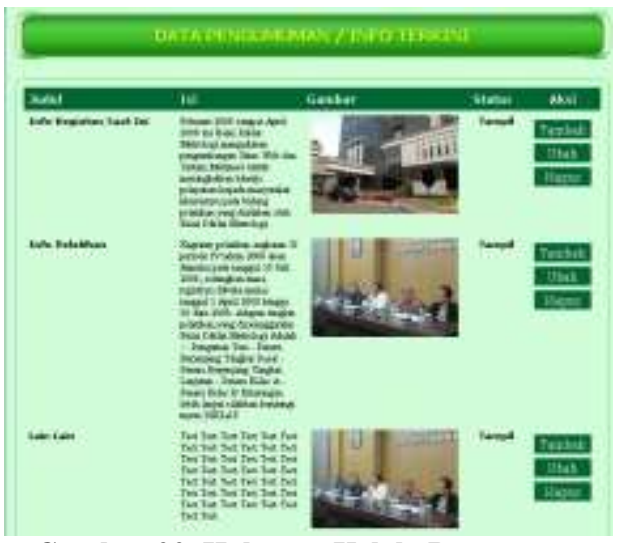

Gambar 22. Halaman Kelola Pengumuman

c) Halaman Kelola Buku Tamu, merupakan halaman untuk mengelola data buku tamu untuk kepentingan kritik dan saran. Kritik dan saran pada halaman ini dibutuhkan untuk membantu menyelesaikan permasalahan Servqual Gap1 agar pihak admin dapat mengetahui apa yang dibutuhkan dan/atau dikeluhkan oleh pengguna fasilitas di Balai 
Diklat Metrologi. Halaman Kelola Buku Tamu dapat dilihat pada Gambar 23 berikut.

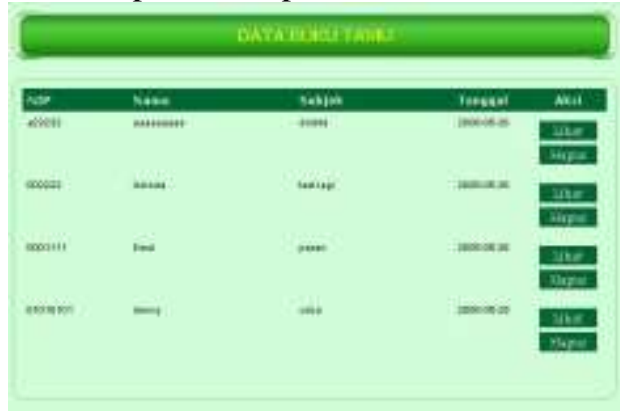

Gambar 23. Halaman Kelola Buku Tamu

d) Halaman Kelola Arsip, merupakan halaman pengaturan arsip dengan format *.pdf yang dapat diunduh oleh peserta. Pada halaman ini, terdapat tanggal input data sebagai indikator history dan flag jika terdapat update data. Hal tersebut diperlukan untuk menyelesaikan permasalahan Servqual Gap4 terkait kualitas data agar agar sesuai dengan kondisi di lapangan. Halaman Kelola Arsip dapat dilihat pada Gambar 24 di bawah ini.

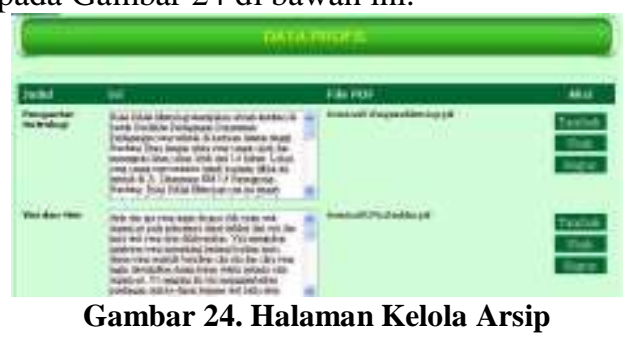

e) Halaman Kelola Galeri, merupakan halaman pengaturan galeri berupa gambar atau foto yang akan ditampilkan. Halaman Kelola Galeri dapat dilihat pada Gambar 25 dan 26 di bawah ini.

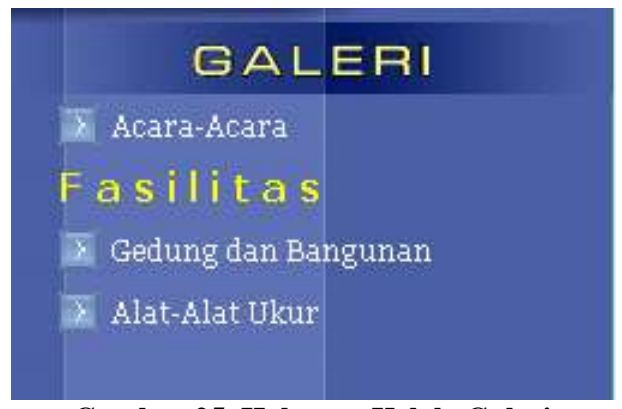

Gambar 25. Halaman Kelola Galeri

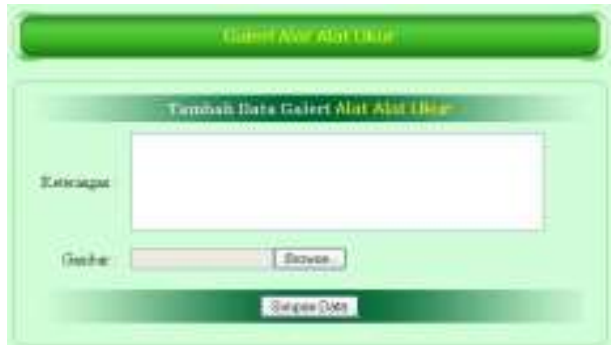

Gambar 26. Halaman Input Data Galeri

f) Halaman Kelola Silabus, merupakan halaman pengatur silabus yang dapat diunduh oleh peserta diklat. Pada halaman ini, terdapat tanggal input sebagai trigger dan/atau kontrol jika silabus harus diperbarui sesuai standar industri. Hal tersebut diperlukan untuk menyelesaikan permasalahan Servqual Gap4 terkait kualitas data agar sesuai dengan materi diklat yang terbaru. Data juga harus disajikan secara detail untuk menyelesaikan permasalahan Servqual Gap 5 terkait harapan dan ekspektasi user. Halaman Kelola Silabus dapat dilihat pada Gambar 27 di bawah ini.

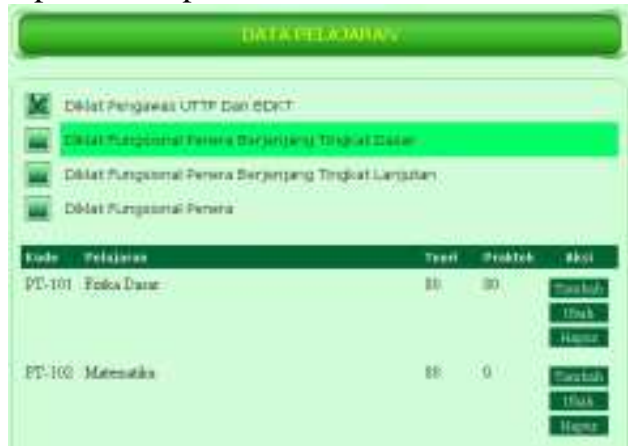

Gambar 27. Halaman Kelola Silabus

g) Halaman Kelola Pengajar, merupakan halaman pengelola data pengajar yang terdaftar pada Balai Diklat Metrologi. Pada halaman kelola pengajar terdapat data masa aktif pengajar sebagai solusi atas masalah Servqual Gap2 terkait standar pelayanan. Halaman Kelola Pengajar dapat dilihat pada Gambar 28 dibawah ini.

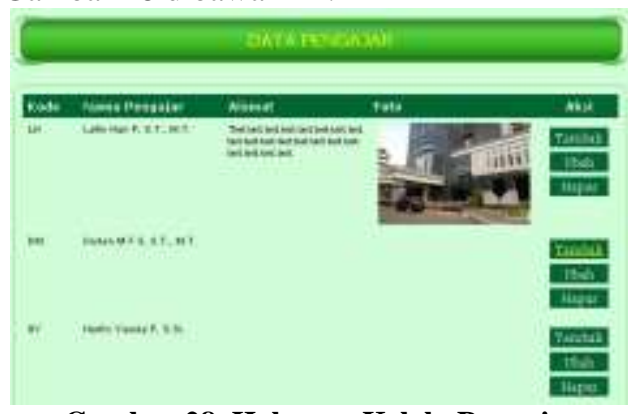

Gambar 28. Halaman Kelola Pengajar

h) Halaman Kelola Jadwal, merupakan halaman pengatur jadwal pelajaran yang diselenggarakan pada Balai Diklat Metrologi. Pada halaman ini juga tidak lupa diberikan informasi detail terkait jadwal agar membantu menyelesaikan masalah Servqual Gap 3. Selain itu untuk menyelesaikan Servqual Gap 2, Admin harus menyesuaikan jurusan pengajar dengan bidang diklat dari setiap peserta. Halaman Kelola Jadwal dapat dilihat pada Gambar 29 di bawah ini. 
Erwin Yulianto ${ }^{1}$,Arief Ginanjar ${ }^{2}$, Pembangunan Sistem Informasi Manajemen Diklat Menggunakan Metode Servqual Dalam Upaya Meningkatkan Kualitas Pelayanan Informasi (Studi Kasus: Balai Diklat Metrologi)

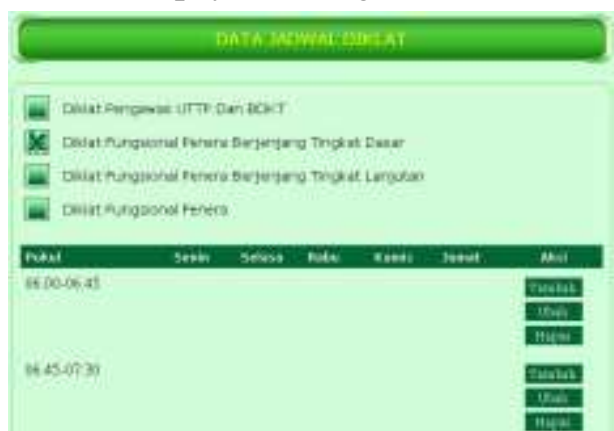

Gambar 29. Halaman Kelola Jadwal

\section{Kesimpulan}

Kesimpulan yang berhasil dicapai pada hasil penelitian antara lain :

1. Dengan adanya Sistem Informasi Manajemen Diklat, para pengguna sistem informasi baik internal maupun eksternal dapat mengakses informasi terkini, mendapatkan update informasi yang dibutuhkan, menyampaikan kebutuhan dan memberikan kritik, ide, dan saran serta informasi di lingkungan Balai Diklat Metrologi sehingga kualitas layanan informasi meningkat.

2. Kinerja Balai Diklat Metrologi meningkat dengan adanya Sistem Informasi Manajemen Diklat dalam hal pengolahan data, penyusunan laporan, dan sentralisasi data untuk mendukung proses penyelenggaraan diklat secara keseluruhan.

3. Dengan adanya Sistem Informasi Manajemen Diklat, kegiatan belajar mengajar dapat dilaksanakan secara efektif dan efisiensi khususnya dalam hal pengolahan data jadwal, kelas, materi diklat, pengajar, peserta diklat maupun nilai.

\section{Daftar pustaka}

[1] Ambar,Manajemen Sumber Daya Manusia, Graha Ilmu, Yogyakarta, 2009

[2] Atmodiwirio, S., Manajemen Training (Pedoman Praktis bagi Penyelenggara Training), Balai Pustaka, Jakarta, 1993

[3] Berry., Parasuraman, A.,Listening to the Customer - The Concept of Building a Service Quality Information System, Sloan Manajemen Review, 1997
[4] Fandy, T., Manajemen Jasa, Andi, Yogyakarta, 1996

[5] Fayol, H., Industri dan Manajemen Umum, Terjemahan Winardi, Sir Issac and Son, London, 1985

[6] Handoko, T., Hani., Manajemen Sumber Daya Manusia, BPFE, Yogyakarta, 2000

[7] Jogiyanto, H., Analisis \& Desain Sistem Informasi : Pendekatan Terstruktur Teori dan Praktek Aplikasi Bisnis, Andi, Yogyakarta, 2001

[8] Ladjamudin, A. B., Analisis dan Desain Sistem Informasi, Graha Ilmu, Yogyakarta, 2013

[9] Notoadmodjo, S., Pengembangan Sumber Daya Manusia, Rineka Cipta, Jakarta, 2009

[10] Parasuraman, A., Valarie A., Zeithmal., Leonard L. B., Delivering Quality Service - Balancing Customer Perception and Expectations, The Free Press, 1990

[11] Pressman, R.S., Rekayasa Perangkat Lunak, Buku Satu, diterjemahkan oleh Harnaningrum L.N., Andi, Yogyakarta, 2002

[12] Sastrohadiwiryo, B.S., Manajemen Tenaga Kerja Indonesia Pendekatan Administratif dan Operasional, PT. Bumi Aksara, Jakarta, 2005

[13] Vennapoosa, C., http://www.exforsys.com/careercenter/project-management-life-cycle/theevolutionary-prototyping-model.html, Exforsys Inc, 2012

[14] Witarto, Memahami Sistem Informasi Pendekatan Praktis Rekayasa Sistem Informasi Melalui KasusKasus Sistem Informasi Di Sekitar Kita, Penerbit Informatika, Bandung, 2004

[15] Wyckof dalam Lovelock C and Wright L,Principle of Service Marketing and Management. Second Edition, Prentice Hall: Person Education International Inc, 1988

[16] Yulianto, E., Suryana, A., Sistem Informasi Penilaian Siswa (Studi Kasus: SLTP Santa Maria Yayasan Salib Suci), Informatics Research \& Development (IRD), Universitas Widyatama, Bandung, 2016, pp. 1-9

[17] Zeithmal, V.A.,Merry, J. B., Service Marketing, 2nd Editions, Mc Graw Hill, NewYork, 2000

[18] Noviastuty, R., Herdiani, L., Ginanjar, A., Perancangan Sistem Integrasi Administrasi Dan Keuangan Dalam Pelayanan Tera dan Tera Ulang Timbangan., Jurnal Tiarsie, Universitas Langlangbuana, Bandung, 2019, pp. 45 - 52. 